\title{
Meat and milk production scenarios and the associated land footprint in Kenya
}

Article in Agricultural Systems · June 2016

DOI: 10.1016/j.agsy.2016.03.003

CITATIONS

0

7 authors, including:

\section{Maarten S. Krol}

University of Twente

85 PUBLICATIONS 1,260 CITATIONS

SEE PROFILE

\section{Jan De Leeuw}

Baku State University

134 PUBLICATIONS 2,141 CITATIONS

SEE PROFILE
READS

124

\section{Mesfin Mergia Mekonnen}

Water for food Institute at University of Nebr... 57 PUBLICATIONS 3,419 CITATIONS

SEE PROFILE

\section{Mats Lannerstad}

International Livestock Research Institute (IL... 22 PUBLICATIONS 450 CITATIONS

SEE PROFILE

Some of the authors of this publication are also working on these related projects:

Project CIM integrated expert GIS and nature conservation at Baku State University View project 


\title{
Meat and milk production scenarios and the associated land footprint in Kenya
}

\author{
Caroline K. Bosire a,b,*, Maarten S. Krol a , Mesfin M. Mekonnen ${ }^{a}$, Joseph O. Ogutu ${ }^{\text {d }}$, Jan de Leeuw ${ }^{c}$, \\ Mats Lannerstad ${ }^{\mathrm{b}}$, Arjen Y. Hoekstra ${ }^{\mathrm{a}}$ \\ a University of Twente, Twente Water Centre, P.O. Box 217, 7522AE Enschede, The Netherlands \\ ${ }^{b}$ International Livestock Research Institute (ILRI), P.O. Box 30709, 00100 Nairobi, Kenya \\ c World Agroforestry Centre (ICRAF), P.O. Box 30677, Nairobi 00100, Kenya \\ d University of Hohenheim, Institute for Crop Science, Biostatistics Unit, 70599 Stuttgart, Germany
}

\section{A R T I C L E I N F O}

\section{Article history:}

Received 6 July 2015

Received in revised form 2 March 2016

Accepted 6 March 2016

Available online $\mathrm{xxxx}$

\section{Keywords:}

Agricultural intensification

Land suitability

Land productivity

Meat

Dairy

Kenya

\begin{abstract}
A B S T R A C T
Increasing demands for meat and milk in developing countries and the associated production growth are driving the expansion of agriculture at the expense of environmental conservation and other land uses. While considerable attention has been directed at improving crop yields to alleviate the pressure on land, there has been far less attention on the implications of the expected intensification of livestock production. Here, we present and analyse the land availability and land footprints of livestock intensification for five scenarios representing various degrees of intensification of meat and milk production by cattle, sheep, goats and camels in arid, semi-arid and humid production systems in Kenya. The first three scenarios are defined by increasing levels of input and management, ranging from low (scenario S1), intermediate (S2) to high (S3) input feed crop cultivation and livestock production. Reference scenario S1 has production practices and output of meat and milk similar to current production practices. In scenarios S2 and S3, the total land used for livestock production remains the same as in S1. Two additional scenarios, S4 and S5, explore opportunities for lessening environmental pressure through reduction of the land footprint of meat and milk production. For each scenario, we quantify the potential availability of grassland and cropland for meat and milk production by cattle, sheep, goats and camel in the arid, semi-arid and humid production systems. A resource use indicator, land footprint (ha), is used to assess changes in land use associated with livestock production. We estimate that the potential increase in production due to intensification from scenario S1 to S2 is 51\% for milk and 71\% for meat. The potential increase due to improving production from scenario S1 to S3 is $80 \%$ for milk and $113 \%$ for meat. The area of grazing land, as a percentage of the total potentially available grazing land, decreases from $10 \%$ to $6 \%$ as productivity increases from scenario S1 to S5. Cropland usage increases from $4 \%$ in scenario S1 to $11 \%$ in scenario S5. Reduced land demand in scenarios S4 and S5 indicates the possibility that intensification may help reduce the pressure on land and hence promote environmental conservation. Overall, the results suggest that it is possible to increase production to meet increasing demands for meat and milk while also gaining land for environmental conservation through intensification. Realizing the potential presented by the intensification scenarios will be contingent upon successfully establishing and operationalizing enabling policies, institutional arrangements and markets and ensuring that relevant information, services, inputs, and other essential requirements are available, accessible and affordable to herders and farmers.
\end{abstract}

@ 2016 Elsevier Ltd. All rights reserved.

\section{Introduction}

Livestock production has significant land, water and carbon footprints. Agriculture appropriates about $40 \%$ of the global terrestrial surface (Foley et al., 2005). Livestock production alone accounts for $70 \%$ of the total agricultural land use, representing one third of all croplands and vast grazing areas (Steinfeld et al., 2006). The total feed biomass used by the

\footnotetext{
* Corresponding author at: University of Twente, Twente Water Centre, P.O. Box 217, 7522AE Enschede, The Netherlands.

E-mail address: c.k.bosire@utwente.nl (C.K. Bosire).
}

livestock sector is considerable and amounts to about 4.7 billion tonnes (dry matter) per year, with about half being grasses and one fourth each being grains and occasional feed and stover (Herrero et al., 2013). Besides its extensive land footprint and significant biomass use, livestock rearing also accounts for almost one third of the agricultural water footprint (Mekonnen and Hoekstra, 2012) and about 15\% of the anthropogenic greenhouse gas emissions (FAO, 2013). In some regions, continued horizontal expansion is a key factor in deforestation (Bilsborrow and Ogendo, 1992; Angelsen, 1995) and in others overgrazing causes severe land degradation (Steinfeld et al., 2006). Not surprisingly, the livestock sector is considered to be one of the leading 
contributors to the increase in environmental degradation (Steinfeld et al., 2006; Pelletier and Tyedmers, 2010).

Global meat and milk consumption is expected to grow significantly by 2030 (Steinfeld et al., 2006). This growth will be particularly pronounced in developing countries where the demand for meat and milk will more than double. The increase in consumption of animal products is driven primarily by population growth, increased purchasing power, and changes in dietary preferences favouring more animal source foods (ASFs), notably meat and milk (Delgado, 2003; Kastner et al., 2012). In addition, efforts to decrease undernourishment globally are also driving the demand for ASFs (Randolph et al., 2007).

In view of the already very large global natural resource use and environmental concerns related to livestock production, many researchers believe a doubling of production in developing countries will need to be met by a sustainable intensification (Pretty et al., 2011; Tarawali et al., 2011). Many developing countries still practice low input agriculture that relies on natural processes and expansion into forested lands, even in high-potential humid regions (Jankhe, 1982; Godfray et al., 2010). This is true for many countries in Africa, where low-input agriculture is still widespread, partly due to limited, or slow uptake of modern production technologies, leading to poor levels of meat and milk production per animal (Headey and Jayne, 2014). Because of poor yields and production for subsistence, production levels in most developing countries are insufficient to meet their domestic demands (Place et al., 2006).

Consequently, large differences exist in livestock productivity between the developed and the developing world, implying a huge untapped efficiency potential in the developing countries, particularly in Africa. Though many interventions have focused on bridging this productivity gap (Tilman et al., 2002), there is a growing realisation that the processes involved in intensification of production of ASFs often overlook environmental impacts (Tscharntke et al., 2012). Studies that assessed these impacts have mainly focused on the implications of increasing yields in croplands on the alleviation of the pressure on the available land (Foley et al., 2005; Koh and Lee, 2012). Very few studies have analyzed the consequences of reduced demand for land through increased productivity in both crop and livestock production (Wirsenius et al., 2010; Tilman et al., 2011).

The production and consumption of livestock commodities in Kenya is a case in point. The demand for livestock commodities is on the rise, and will likely continue to rise in the near future (Omore et al., 1999). Several studies have assessed farmer responses to increasing demand and showed how these are closely linked to the wider institutional, social and cultural context and how they relate to economic factors, which differ across farming systems (Feder and Umali, 1993; Marra et al., 2003; Owen et al., 2012). However, the availability of and demand for land to meet livestock production needs across the various farming systems has not been quantified for Kenya. Additionally, the implications of both cropland and livestock productivity improvements for various production systems have not been quantitatively analysed and documented. Understanding of these issues is essential for the development and deployment of sound policies and practices that ensure that increased livestock production through intensification is in synergy with other critical targets such as biodiversity conservation and improved nutrition in Kenya. This paper aims to enhance our understanding of land use and availability by examining the intensification potential of meat and milk production by four ruminant species, namely cattle, shoats (sheep and goats) and camels in Kenya. The specific objectives of this paper are two-fold: (1) assess the availability and suitability of land for meat and milk production in three production systems, and; (2) explore options for intensification to either expand production of meat and milk or relieve pressure on existing lands in Kenya.

\section{Methods and data}

In this paper we assess land availability, suitability and livestock production and the gains in land savings that can be expected from increasing the production of four ruminant livestock species under three intensification scenarios in Kenya as illustrated schematically in Fig. 1. We do not consider meat production from poultry and pigs as they currently constitute a minor proportion of the total meat production in Kenya relative to ruminants (Bett et al., 2012).

\subsection{Identification of land available for livestock production}

\subsubsection{Selection and characterisation of analysis unit}

We analyse the production systems for four ruminant species, namely cattle, shoats, and camels in Kenya. Each production system is characterised by specific agro-ecological factors (Pratt and Gwynne, 1977; Grandin, 1988; Rege, 2001). Land available for livestock production is estimated for each of the three agro-climatic regions, i.e. humid, semi-arid and arid. Each of these three distinct geographical regions is referred to as a production system.

The humid production system is located in areas with high potential for crop, fodder and livestock production, due to fertile soils, annual rainfall averaging over $800 \mathrm{~mm}$, and modest pest and disease problems. It covers large parts of Central Kenya, the Central Rift Valley, Western Kenya and most of the Coastal strip (Ouma et al., 2000). The semi-arid production system has a medium potential for plant growth and livestock production, an average annual rainfall of $600-800 \mathrm{~mm}$ and a high prevalence of trypanosomiasis. This production system covers parts of Eastern Kenya, neighbouring the highland production systems to the north and south, and the coastal strip to the west. The arid production system has the lowest potential for biomass and livestock production. This system is characterised by an average annual rainfall of less than $600 \mathrm{~mm}$, high variability in rainfall amount in both the wet and dry seasons, and high prevalence of various livestock diseases (Grandin, 1988; De Leeuw and Rey, 1995; Ndambi et al., 2007). The arid and semi-arid systems cover about $83 \%$ of the total land area of Kenya and are home to about 35\% of Kenya's population. In contrast, the humid system covers only about 17\% (Ruigu, 1988).

\subsubsection{Land available for agriculture}

The land area directly available for ruminant production in the three production systems in Kenya includes grazing lands, for grazing and browsing livestock, and feed crop areas, for cultivation of fodder and feeds. However, the potential land available for livestock production also includes grasslands suitable for crop production and currently used for grazing. The land currently available for livestock and crop production in each of the delineated production systems was estimated by masking the land use systems raster obtained from the FAO (2010) by the production systems polygon (Robinson et al., 2011). The detailed classification systems used in Robinson et al. (2011) are reclassified into the three agro-climatic zones above as described in Bosire et al. (2015). Fig. 2 illustrates the estimates of land area currently available for livestock and crop production in each of the three production systems under each of three production scenarios.

The total area of land $L_{\text {total }}[s]$, constituting production system $s$ (arid, semiarid, humid) can be partitioned into the total grassland area ( $L_{\text {grassland }}[s]$ ) plus other environmentally valuable areas, such as forests and other protected areas with restricted access for livestock rearing $L_{e n v}[s]$, cropland used for food and feed production $L_{\text {crop }}[s]$, and unproductive areas, including built-up, degraded and bare areas that are unsuitable for agricultural production $\left(L_{\text {unprod }}[s]\right)$. Therefore, the total land area for livestock and crop production in each production system $L_{\text {agric }}[s]$ is determined by:

$L_{\text {agric }}[S]=L_{\text {grassland }}[S]+L_{\text {crop }}[S]$.

The cropland used for feed production $L_{\text {feedcrop }}[s]$ quantifies the feed-crop land footprint (Bosire et al., 2015) and is calculated as the proportion of cropland $L_{\text {crop }}[s]$ that is specifically used for feed crops, forages such as alfalfa and Napier grass. Likewise, the grassland used by livestock quantifies the grassland footprint $L_{\text {grazing }}[s]$. By adding the 


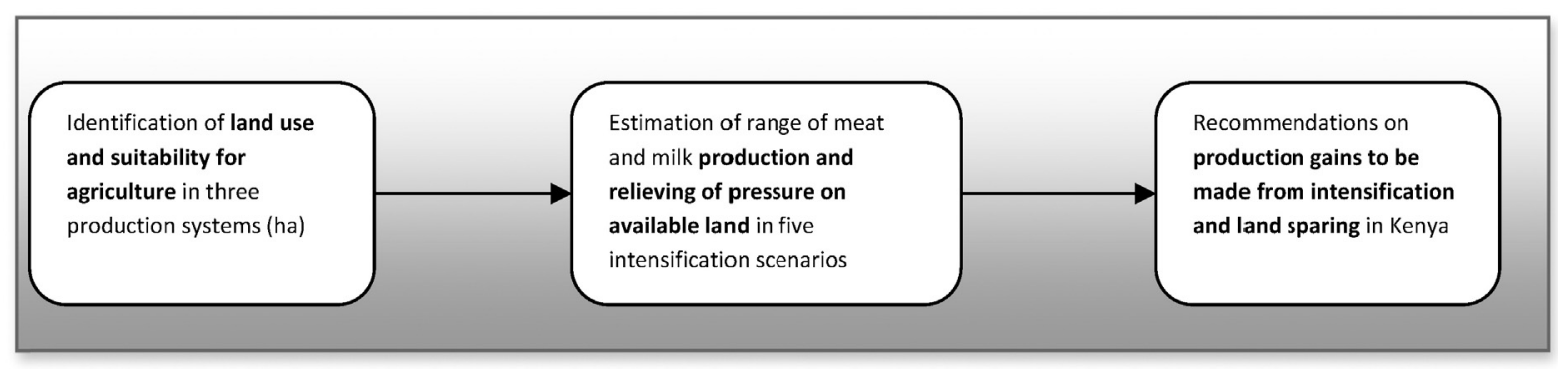

Fig. 1. Steps involved in the assessment of land availability, suitability and potential for livestock production under five intensification scenarios.

feed cropland and grassland footprints we get the total land use footprint for livestock $L_{\text {livestock }}[s]$.

\subsection{Land suitability estimation}

Under intensified production, livestock dietary composition increasingly includes higher proportions of feed crops. We thus determine the extent of land suitable for the production of both food and feed crops in Section 2.2.1 and outline five scenarios of intensification of livestock production in Kenya in Section 2.3.

\subsubsection{Land suitability for food and feed crop cultivation}

Intensification of ruminant livestock production systems is generally correlated with an increase in the fraction of supplemental and compounded feeds in the animal diets (Herrero et al., 2013) and thus with increased use of cropland for feed crop production. We consider only grassland suitable for cultivation (Fig. 3) as available for conversion into land for feed production in the semi-arid and humid systems (S2 and S3) (Fig. 2). The baseline scenario (S1) for land available for livestock production corresponds to the current pattern of land used for grazing and feed crop cultivation as described in Bosire et al. (2015).

Global grazing and cropland suitability maps (van Velthuizen et al., 2007) were used to determine the land potentially available for feed crops within the land areas currently available for pasture or crop production. In these maps, land suitability is provided for pasture or crop production for 2.2 million grid cells of 5 by $5^{\prime}$, classified as either rainfed or irrigated, and distributed across three input and management levels, i.e. low, intermediate and high.

A crop suitability index (CSI) can be derived for a combination of crop types, under both rainfed and irrigated conditions, and at the three levels of input and management. CSI is defined as the proportions of maximum yields of crops that can be achieved in a grid cell under appropriate management (van Velthuizen et al., 2007). Crop suitability indices range from 0 to 100 , with 0 representing not suitable and 100

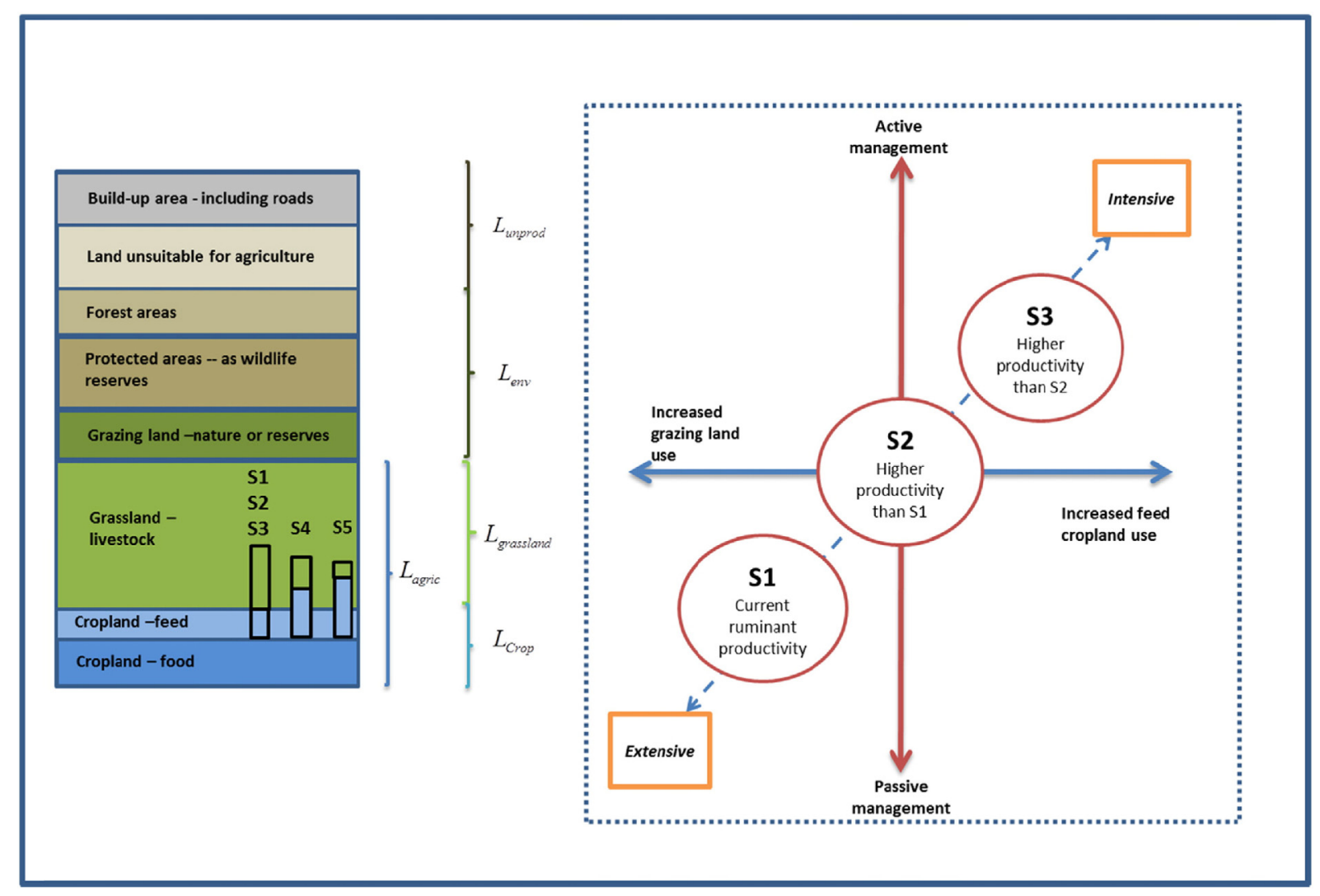

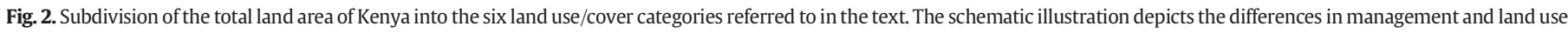

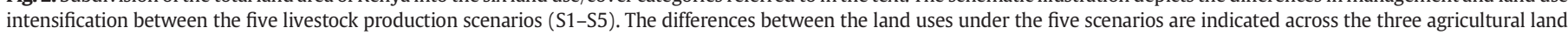
areas. 


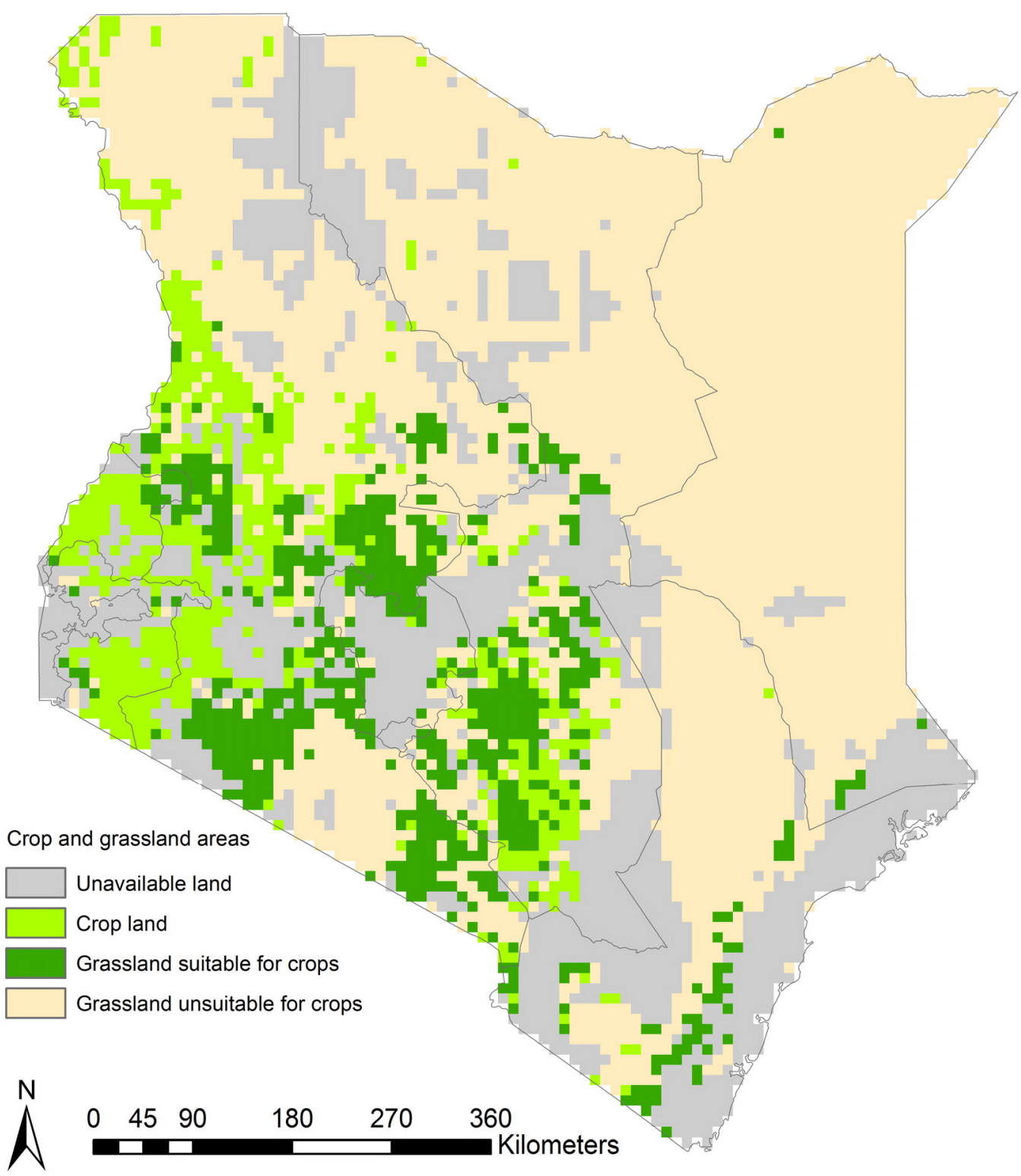

Fig. 3. A map of Kenya showing the distribution of cropland, the land unavailable for agriculture, the grasslands and their suitability for crops.

very high suitability. We consider lands with CSI between 0 and 50 (medium suitability) as unfit for feed crop cultivation and thus exclude them from the subsequent analyses (Section 2.1.2). Land with CSI values of 51-100, ranging from medium, high to very high suitability, are included as potentially available areas for feed cultivation under scenarios S1 to S3.

\subsection{Intensification: quantifying the maximum production potential with current livestock numbers}

We define five intensification scenarios using a set of assumptions relating to land availability for livestock production and the potential production of meat and milk by cattle, shoats and camels in each of the three preceding production systems. We distinguish three levels of input and management, ranging from low input rainfed to high input irrigated cultivation defined by van Velthuizen et al. (2007).

The first scenario, S1, is the baseline scenario and represents low production of meat and milk. For the baseline it is assumed that livestock is produced under conditions of low inputs and traditional management. Livestock production is also assumed to be primarily for subsistence and not markets. Furthermore, it is assumed that the production system is not mechanized, no fertilizers or chemicals are used to control pests or diseases and that no measures are taken to prevent land degradation. As agricultural production in Kenya is predominantly carried out by smallholder farmers, with little farmland under irrigation (about $0.07 \%$ ) (Ngigi, 2002), these characteristics are typical of the current livestock production practice in Kenya.

Scenarios S2 and S4 assume intermediate production of meat and milk under both rainfed and irrigated agriculture, with intermediate inputs and intermediate management. Manual labour and animal traction are used, some fertilizer is applied and some chemicals are used for pest or disease control. There are fallow periods and certain measures are taken to prevent land degradation. In scenario S2 the total land footprint of livestock production is kept constant, with increasing milk and meat outputs, while in scenario S4 milk and meat outputs are kept constant, with a decreasing total land footprint of livestock production (Table 1).

Scenarios S3 and S5 represent high production of meat and milk, under both rainfed and irrigated agriculture, characterised by the use of high inputs and advanced management. Agricultural production is mechanized and improved high-yielding feed crop varieties are widely 
Table 1

Summary of factors determining production intensification under the five scenarios. For details and references on each factor refer to the text.

\begin{tabular}{|c|c|c|c|c|c|}
\hline \multicolumn{2}{|c|}{ Scenario constraints } & \multicolumn{2}{|c|}{$\begin{array}{l}\text { Increase in production while keeping land footprint } \\
\text { of livestock production constant in all production systems }\end{array}$} & \multicolumn{2}{|c|}{$\begin{array}{l}\text { Reduction in land footprint of livestock production while keeping } \\
\text { meat and milk production constant in all production systems }\end{array}$} \\
\hline $\begin{array}{l}\text { Factors of } \\
\text { production }\end{array}$ & Scenario S1 (reference) & $\begin{array}{l}\text { Scenario S2 (intermediate } \\
\text { intensification) }\end{array}$ & $\begin{array}{l}\text { Scenario S3 (high } \\
\text { intensification) }\end{array}$ & $\begin{array}{l}\text { Scenario S4 (intermediate } \\
\text { intensification) }\end{array}$ & $\begin{array}{l}\text { Scenario S5 (high } \\
\text { intensification) }\end{array}$ \\
\hline Land use & $\begin{array}{l}\text { Grazing land and minimal } \\
\text { cropland use }\end{array}$ & $\begin{array}{l}\text { Grazing land and conversion of } \\
\text { suitable grazing land into feed } \\
\text { cropland }\end{array}$ & $\begin{array}{l}\text { Grazing land and conversion of } \\
\text { suitable grazing land into feed } \\
\text { cropland }\end{array}$ & $\begin{array}{l}\text { Grazing land and conversion of } \\
\text { suitable grazing land into feed } \\
\text { cropland }\end{array}$ & $\begin{array}{l}\text { Grazing land and conversion of } \\
\text { suitable grazing land into feed } \\
\text { cropland }\end{array}$ \\
\hline $\begin{array}{l}\text { Feed } \\
\text { composition }\end{array}$ & $\begin{array}{l}\text { Mainly pasture with } \\
\text { minimal fodder and } \\
\text { compounded feeds }\end{array}$ & $\begin{array}{l}\text { Mainly pasture and higher } \\
\text { proportion of crop based feeds } \\
\text { than in S1 }\end{array}$ & $\begin{array}{l}\text { Pasture and higher proportion } \\
\text { of crop based feeds than in S2 }\end{array}$ & $\begin{array}{l}\text { Mainly pasture and higher } \\
\text { proportion of crop based } \\
\text { feeds than in } \mathrm{S} 1\end{array}$ & $\begin{array}{l}\text { Pasture and higher proportion } \\
\text { of crop based feeds than in S4 }\end{array}$ \\
\hline $\begin{array}{l}\text { Land } \\
\text { productivity }\end{array}$ & Current & + & ++ & + & ++ \\
\hline $\begin{array}{l}\text { Feed } \\
\text { Conversion } \\
\text { Efficiency } \\
\text { (FCE) }\end{array}$ & Current & + & ++ & + & ++ \\
\hline $\begin{array}{l}\text { Livestock } \\
\text { productivity }\end{array}$ & Current & + & ++ & + & ++ \\
\hline
\end{tabular}

used. In scenario S3, the total land footprint of livestock production is kept constant, with increasing milk and meat outputs, while in scenario S5 milk and meat outputs remain constant, with decreasing total land footprint of livestock production.

\subsubsection{Eight factors determining production under the five scenarios}

The following eight factors determine the production potential for meat and milk in the five scenarios: 1) types of land used, 2) feed composition, 3) land productivity, 4) feed conversion efficiency, 5) livestock productivity, 6) ratios of the different livestock species, 7) livestock breeds, and 8) ratios of meat and milk produced. For meat production we analyse the role of all these factors for all four livestock species in each of the three production systems. We similarly evaluate the influence of these factors on milk production except for shoats and camels in the humid production system where they are not typically reared for milk production.

2.3.1.1. Land use. We classify agricultural land use into either grazing or cropland and make assumptions on their availability to livestock based on where they occur in each of the production systems. For the arid production system we assume that there is no cropland available for feed cultivation.

We assume that an increase in meat and milk production is associated with a higher fraction of compounded and supplemental feeds in the diet. This is consistent with the observed increase in the amount of feed crops in the diets of ruminants as the production output per animal increases from the arid to the humid production system. Thus, the three productivity scenarios represent distinct stages along a gradient of increasing intensification, dependent on expansion of feed crop cultivation onto grasslands suitable for crop production. The expansion of feed crops can be expected to directly compete with food production because both require arable land. Even so, we still chose to assign additional land to meet increased feed demand for ruminant production by converting arable grazing land to feed crop cultivation (Fig. 2).

The five production scenarios also differ with respect to restrictions placed on expansion of land cultivated for feed crops. Under scenario S1, feed cultivation is not allowed to expand and the entire livestock production enterprise only occurs on grazing land and minimal cropland. Feed cultivation can expand but only onto grazing land in scenarios S2 to S5. Recall that only grazing land of medium to high suitability for crop production can be converted to cropland in the semi-arid and humid production systems.

2.3.1.2. Feed composition. We assume that a higher output of meat and milk can be achieved by including crop residues and compounded and supplemental feeds in the livestock diet. Such an improved feed composition, blending grains, cereals and minerals rich in energy and low in fibre, makes it possible to meet production objectives centred on improved animal growth, weight gain, milk output, and general health.

For scenario S1, we assume the current diet composition, including minimal crop residue, compounded and supplemental feeds in the diets, i.e. the current application levels in the semi-arid and humid production systems (Bosire et al., 2015). For scenarios S2 and S4, we specify an improved diet containing higher proportions of fodder, crop residues and compounded and supplemental feeds. Scenarios S3 and S5 assume current diets containing the highest possible levels of compounded and supplemental feeds for meat and milk producing livestock in Kenya based on values reported by case study farms and by Bouwman et al. (2005).

2.3.1.3. Breed of livestock and feed conversion efficiency. Both improved breeds and higher feed conversion efficiency (FCE) contribute to increasing productivity. Indigenous breeds, mixed breeds (Guernsey, Jersey, Ayrshire and Friesian dairy stock, crosses between these European breeds, and crosses between the European breeds and Zebu type cattle typically kept in the humid production system), pure or exotic breeds in the production systems are associated with low, intermediate and high meat and milk output, respectively. FCE is defined as feed use per unit of output produced by each species and in each of the three production systems. It is expressed in terms of dry weight of feed intake per fresh weight of meat or milk produced. Improved FCE is assumed to be the main driver for increasing the productivity of the four ruminant species. We base the FCE calculations on Bouwman et al. (2005), calibrated with values derived from field visits to case study farms representing different stages of intensification of meat and milk production in Kenya.

Scenario S1 represents mainly indigenous breeds in the arid and semi-arid systems and mixed breeds in the humid system characterised by comparatively low productivity per animal due to low FCE and poor diets. Although the indigenous breeds have certain qualities, such as drought and disease tolerance, that make them more suitable for production under the conditions assumed in scenario S1, we focus only on their inherent productivities. In scenarios S2 and S4, productivity improvement is achieved by cross-breeding the indigenous and exotic species, leading to breeds with improved FCE derived from the exotic breeds and disease and drought resistance traits inherited from the indigenous breeds. Livestock breeds in scenarios S3 and S5 have the highest FCE, usually associated with the exotic or pure breeds, such as the Boran cattle.

2.3.1.4. Livestock productivity. Livestock productivity (meat and milk production per animal) is a function of the FCE, breed and the diet composition. We determine animal productivity in the five scenarios in Kenya based on values reported by case study farms and by Bouwman 
et al. (2005) for all scenarios except scenario S1 in which values are the same as those in Bosire et al. (2015).

2.3.1.5. Land productivity. Land productivity is a function of the amount of precipitation, soil type, crop and level of input. We consider the minimum, mean and maximum productivity of the grass, fodder crops, maize and wheat for grazing and croplands to represent the three scenarios (Ouda, 2001; Mekonnen and Hoekstra, 2011). Maize and wheat are included in the analyses because they constitute a large proportion of the compounded and supplemental feeds in Kenya (ILRI, 2010). Under scenarios S2 to S5, we consider the land productivities under the grazing land conversion option presented in Section 2.3.1.1.

2.3.1.6. Ratios of ruminant species and ratio of meat to milk production. For all scenarios, we assume that the production systems have settled at an equilibrium based on the prevailing climate, market systems and other factors determining production practices. Therefore, we keep the livestock number constant and maintain current proportions of meat and milk production distributed over the three species in the arid, semi-arid and humid production systems in Kenya. These factors are a proxy for economic drivers of livestock production and quantify the ratio of usage of products of animals of each species based on the prevailing market access infrastructure.

\subsection{Maximum production potential with current total land use}

Intensification can make it possible to increase production and meet rising demand for ASFs without increasing the amount of land used. To estimate the production increase with intensification, we maintain the total land used for milk and milk production as in scenario S1 and estimate the expected quantities of milk and meat produced with increased productivity for scenarios S2 and S3. The highest potential production of meat and milk by species $a$ in production systems $s$, considering improved land productivity in $\mathrm{S} 2$ and $\mathrm{S} 3, P P_{\text {meat \& milk }}[\mathrm{a}, \mathrm{S}]$ (tonne), is estimated as the total land used to produce meat and milk, $L L U_{\text {meat } / \text { milk }}[a, s]$ (ha), by species $a$ in production systems $s$, divided by $L_{\text {livestock }}[a, s]$, the land footprint (ha/t) for species $a$ in production system $S$

$P P_{\text {meat } / \text { milk }}[a, s]=\frac{L L U_{\text {meat } / \text { milk }}[a, s]}{L_{\text {livestock }}[a, s]}$

\subsection{Estimating land use for livestock production}

To understand how the anticipated trajectory of intensification will affect demand for land we estimate land use under intensification as outlined in Fig. 2. We keep the total land use for milk and meat production constant and equal to the estimates reported in Bosire et al. (2015) in scenarios S1, S2 and S3. Total land use for production under scenarios S4 and S5 is derived with Eq. (2), keeping the total meat and milk production constant.

Due to the difficulty of acquiring some of the relevant data for sheep, goats and camel production we make certain simplifying assumptions for each species across the five scenarios. For sheep and goats, only improvements in meat production are calculated, while milk productivity is assumed to be static. The productivity of both milk and meat by camels is also assumed to be static.

\subsection{General limitation of data and methods}

Estimating the total potential livestock production requires detailed information on all the ruminant and monogastric species in each production system. This was not always possible because reliable long-term information on several species such as chicken and pigs was not available. As we were unable to find evidence for improved productivity for camel using ground truthing in the case study farms, we assumed no intensification of camel production under the three scenarios of improved management. Therefore, in estimating the total potential output of ruminants in Kenya, we assume that the camel output is maintained at the current levels of management to circumvent this limitation. However, camel production is quite small relative to cattle and shoats, about $9 \%$, and so the overall results should be largely unaffected by this assumption and representative of the different scenarios.

Available data on livestock numbers for the three production systems selected for this study are also limited. We therefore used data from aerial surveys conducted by the Kenya Directorate of Resource Surveys and Remote Sensing (DRDRS) from 2000 to 2012 to estimate the numbers of livestock in each of the three production systems. Our values for milk and meat production for Kenya, especially for cattle, therefore differ from those used by the Food and Agriculture Organization (FAOSTAT) and Behnke and Muthami (2011), derived from the 2009 national census data. Inconsistencies in spatial layers used to infer land suitability, crop yields and land availability can potentially add a level of inaccuracy in estimates of key parameters used in this study. Such a mismatch was, however, not encountered when down-scaling the global availability, suitability and crop yield estimates to the national production system level.

\section{Results}

We first present the results on land use and production potential. Tables 2-4 summarise the results on major land uses whereas Figs. 35 depict the findings on the production parameters.
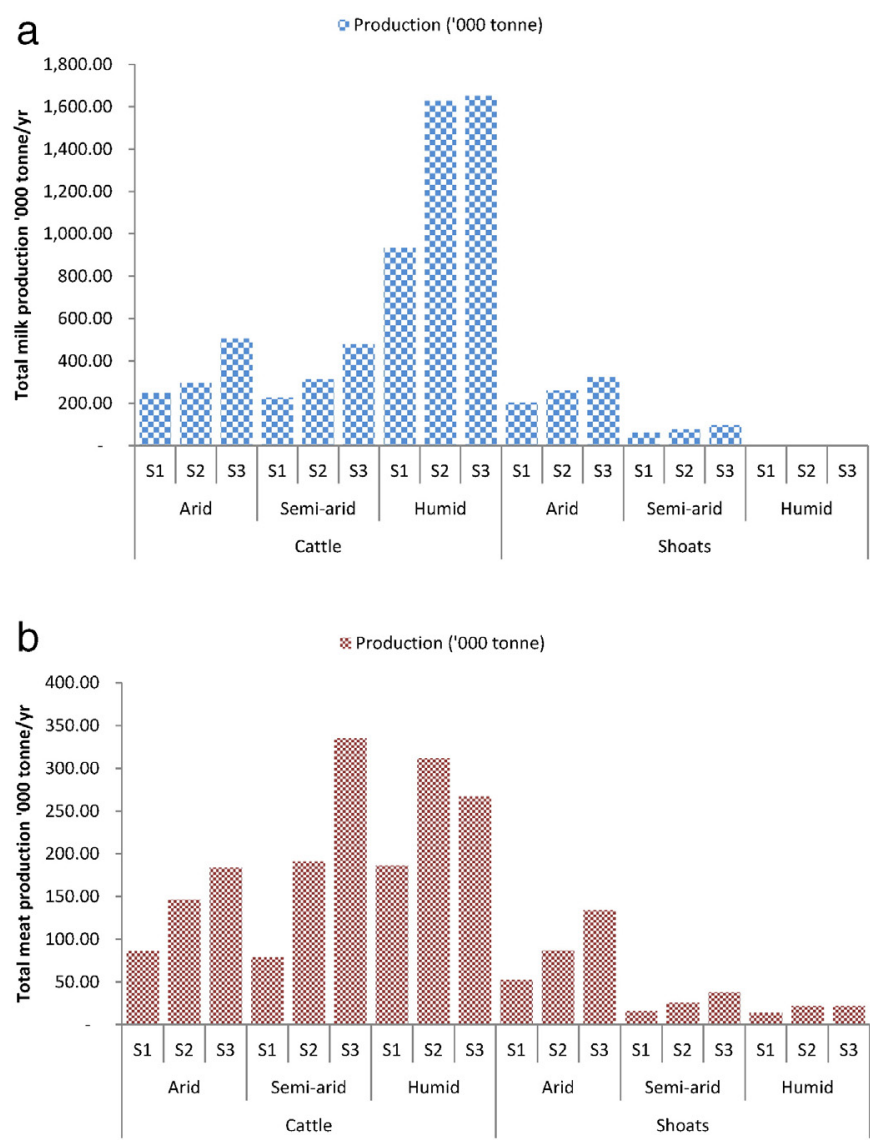

Fig. 4. a: Milk production potential of three livestock species estimated for each of the three production systems (arid, semi-arid and humid) under scenarios S1 to S3. b: Meat production potential of three livestock species estimated for each of the three production systems (arid, semi-arid and humid) under scenarios S1 to S3. 

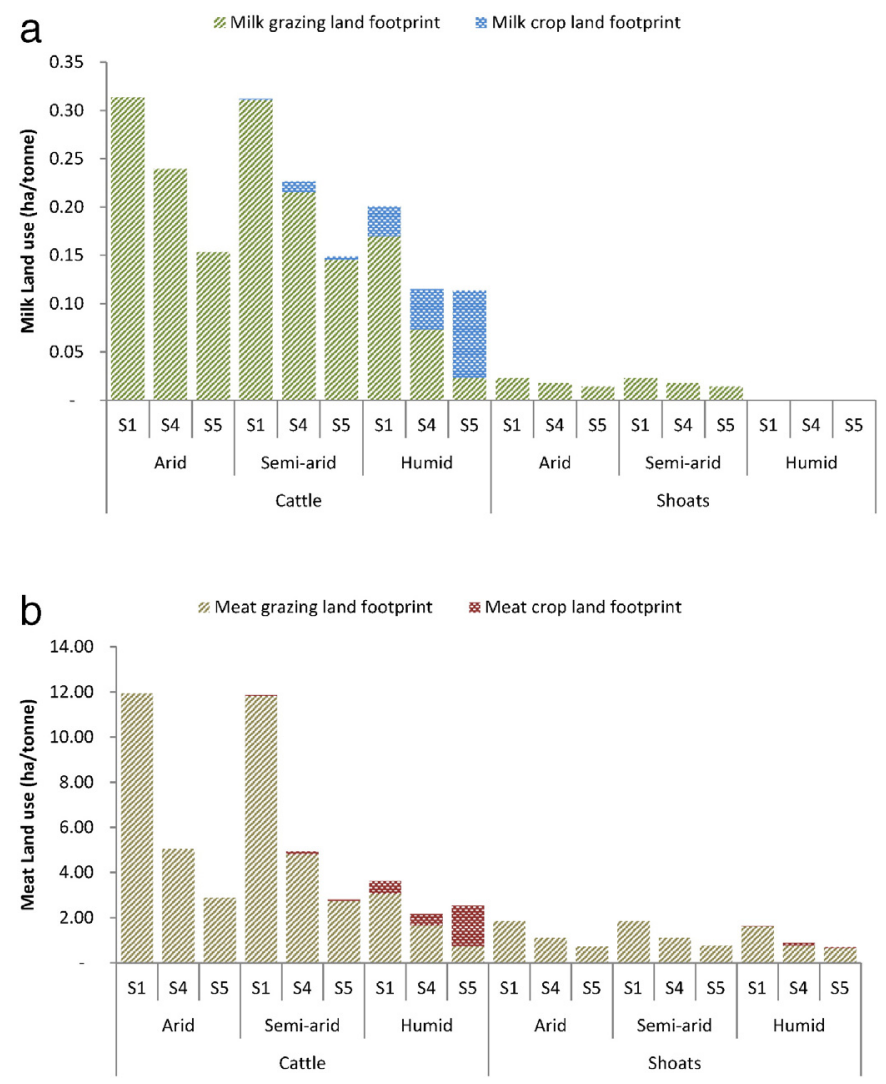

Fig. 5. a: Land productivity for milk under each of the three production systems (arid, semi-arid and humid) for scenarios S1-S5. b: Land productivity for meat in each of the three production systems (arid, semi-arid, humid) for scenarios S1-S5.

\subsection{Total agricultural land and suitability for crop production}

Assessment of the total land available for agricultural production showed that 12,912,300 hectares (ha) (23\%) of Kenya's total land area is unavailable for livestock production (Fig. 2 and Table 2). The remaining $43,679,900$ ha (77\%) of Kenya's land area that qualifies as agricultural lands consists of grasslands (68\%) and croplands (9\%). The arid production system covers nearly $34,307,400$ ha (79\%) of the national agricultural land, and consists mainly of vast grasslands. The semi-arid and humid systems cover 3,843,700 ha (8\%) and 5,528,800 ha (13\%) of the remaining total agricultural land, respectively.

The suitability analysis shows that $12 \%$ of the total agricultural land can be classified as land with medium to very high suitability for cropping (Table 1). However, the precise percentage coverage of this category varies widely across the different production systems, from $42 \%$ in the semi-arid system to $64 \%$ in the humid production system. No suitability estimates were made for the arid production system as crop cultivation is not currently practiced in this system. Land of low suitability for crop production is highest in the semi-arid production system, comprising $58 \%$ of the total agricultural land in this production system.

When considering only grasslands, the humid production system displays the highest share (69\%) of the land suitable for crop production. In contrast, about $34 \%$ of the grasslands in the semi-arid production system appear to be suitable. Strikingly, $36 \%$ of the cropland currently cultivated in all the three production systems in Kenya fall into the medium to very high suitability categories. For both the humid and the semi-arid systems the fraction of land that is suitable for crops and used for crop cultivation is about $60 \%$.

\subsection{Land available for agriculture in Kenya}

Table 3 shows the estimates of land used for both livestock and crop production and the land currently used for agriculture. As we consider only the land for agriculture, the estimate for the total land used for agriculture is lower than that potentially available for agricultural production by $3 \%$ due to the exclusion of cropland from the arid system. Grasslands in the arid system constitute most (88\%) of the land used for agriculture. The humid and semi-arid systems have the second largest (13\%) and smallest (9\%) fractions, respectively, of land that can be used for agricultural production. Overall, about $9 \%$ of grassland in Kenya is currently used for livestock production. The highest proportion of grassland currently used for livestock production (37\%) is in the semiarid system. The humid system has $22 \%$ of the grassland currently used for livestock production while $6 \%$ of grassland is used in the arid system. The overall use of feed cropland is $5 \%$ of the total cropland for agriculture. Humid systems have the largest proportion (6\%) of agricultural cropland that is used for feed crop production.

Table 2

The total land area (ha) and suitability estimates (ha) for grasslands and croplands used for both livestock and crop production in the three production systems in Kenya, for the baseline scenario (S1), representing the currently prevailing production practice.

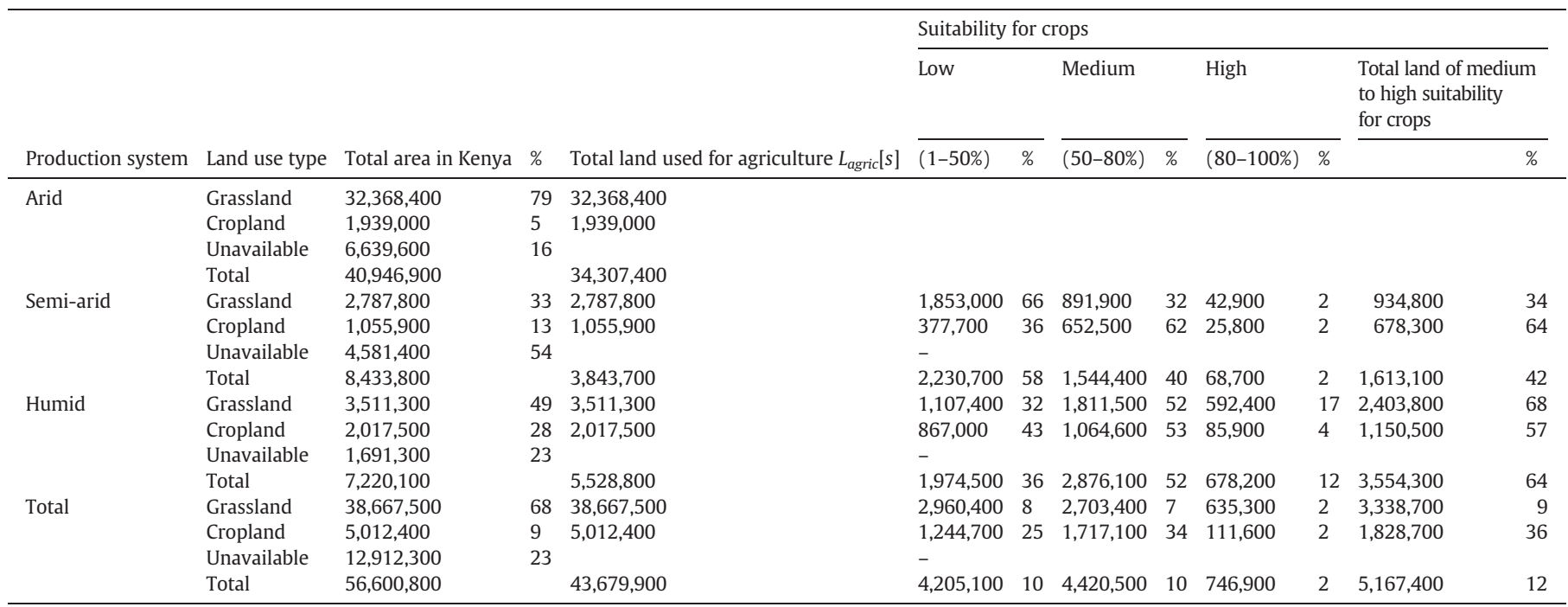


Table 3

The total land area used for agriculture (ha), land currently used for agriculture (ha) in grasslands and croplands for both livestock and crop production and the current land footprint of livestock in three production systems in Kenya.

\begin{tabular}{lllll}
\hline $\begin{array}{l}\text { Production } \\
\text { system }\end{array}$ & $\begin{array}{l}\text { Land use } \\
\text { type }\end{array}$ & $\begin{array}{l}\text { Total land } \\
\text { used for } \\
\text { agriculture } \\
\left(L_{\text {agric }}[s]\right)\end{array}$ & $\begin{array}{l}\text { Current land use } \\
\text { for agriculture } \\
\left(L_{\text {grazing }}[s]+L_{\text {crop }}[s]\right)\end{array}$ & $\begin{array}{l}\text { Current land use } \\
\text { for livestock } \\
\text { production } \\
\left(L_{\text {livestock }}[s]\right)\end{array}$ \\
\hline \multirow{4}{*}{ Arid } & Grassland & $32,368,400$ & $1,915,650$ & $1,915,650$ \\
& Cropland & - & - & - \\
& Total & $32,368,400$ & $1,915,650$ & $1,915,650$ \\
\multirow{2}{*}{ Semi-arid } & Grassland & $2,787,800$ & $1,045,000$ & $1,045,000$ \\
& Cropland & $1,055,900$ & $1,055,900$ & 4850 \\
\multirow{3}{*}{ Humid } & Total & $3,843,700$ & $2,100,900$ & $1,049,850$ \\
& Grassland & $3,511,300$ & 752,100 & 752,100 \\
& Cropland & $2,017,500$ & $2,017,500$ & 132,400 \\
\multirow{2}{*}{ Total } & Total & $5,528,800$ & $2,769,600$ & 884,500 \\
& Grassland & $38,667,500$ & $3,712,750$ & $3,712,750$ \\
& Cropland & $3,073,400$ & $3,073,400$ & 108,200 \\
& Total & $41,740,900$ & $6,786,150$ & $3,850,000$ \\
\hline
\end{tabular}

\subsection{Production potential of meat and milk under increasing intensification under current land use}

Scenario S3 represents the configuration of factors that ensures the highest output of milk and meat (Fig. 4a). Milk production increases with improved intensification from scenarios S1 to S3 by between $51 \%$ and $80 \%$. The total milk production is consistently higher in the humid production system in all scenarios. The semi-arid system shows the largest increase (99\%) in milk production across all the systems as productivity increases from S1 to S3, mainly associated with improved milk yields by cattle. The humid system has consistently high increase in production as intensification increases from scenario S1 to S3, while the arid system has the lowest increase in production (24\%) with increasing intensification from scenario S1 to S2.

Meat production increases in the arid (99\%) and the semi-arid (290\%) systems as intensification increases from scenario S1 to S3 (Fig. 4b). The potential for improving livestock productivity is much larger for cattle in these systems than in the humid system where there is a decline in meat production (14\%) with increasing intensification from scenarios S2 to S3. This points to greater constraints to improving cattle yields in the humid system than in the arid and semi-arid systems, leading to smaller productivity increases in the humid system. A better FCE for this scenario would lead to higher meat production in the humid system. Similarly for shoats, the carcass yield increases by $33 \%$ and $50 \%$ in all the production systems as intensification progresses from scenarios S1 to S2 and S1 to S3, respectively. This leads to elevated meat production with advancing intensification from scenarios S1 to S2 of $31 \%$ and $\mathrm{S} 1$ to $\mathrm{S} 3$ of $61 \%$.

\subsection{Increase in production potential and growth in per capita supply of milk} and meat

Milk and meat represent a large proportion of the expenditure of many households (Bett et al., 2012). Here, we only consider milk and meat production per capita after intensification in all the production systems throughout Kenya. The increase in per capita supply of meat and milk from cattle is the highest and ranges between $77 \%$ and $88 \%$ across all the three scenarios. The percentage increase in the per capita supply of beef with advancing intensification from scenario S1 to S3 of $67-72 \%$, representing 9 to $14 \mathrm{~kg}$ per year, is the largest recorded. Even though the current supply rate is lower than the FAO food balance of national production estimate of $11.3 \mathrm{~kg}$ per capita of beef supply per year for Kenya, our estimated range of increased supply does not deviate much from this estimate.

\subsection{Potential for resource savings under increasing intensification}

Table 4 shows that in all systems, there is a general decline in the total land used for livestock production with improved productivity from scenarios S1 to S5. The semi-arid system has the highest overall use of available agricultural land for livestock production. However, for the humid system, the total cropland used for livestock production increases from scenarios S2 to S3 as the assumed productivity increase requires improving diets with supplemental and compounded feeds, the production of which would require converting about 600,000 ha of land that is currently not used for feed cultivation into croplands. The smallest area of grassland used for ruminant production is in the arid system in scenario S5. By contrast, the largest area of cropland used for livestock production is in scenario S3 in the humid production system. In order to have a comprehensive indication of land potentially available for expansion of feed crop production, we focus on the land currently classified as grasslands and suitable for crop production in Section 3.1. In all the scenarios, the demand for cropland to produce feed does not exceed the proportion of grassland that is considered to be of medium to high suitability for crop production. This indicates that improving productivity as proposed in this analysis is unlikely to lead to increased competition between feed and food production on the current cropland.

Land use per tonne of product in scenario $\mathrm{S} 3$ is the lowest across all the production systems (Fig. 5a-b) mainly due to the improvement in ruminant productivity of meat and milk and drop in the use of grasslands. The converse is the case for the use of cropland, which increases from $0.27 \mathrm{ha} / \mathrm{t}$ to $0.33 \mathrm{ha} / \mathrm{t}$ for meat production as the level of intensification

Table 4

The total land use (ha) for meat and milk production in each production system under the five scenarios, with the total output kept at the baseline production levels (scenario S1).

\begin{tabular}{|c|c|c|c|c|c|c|}
\hline \multirow{3}{*}{$\begin{array}{l}\text { Production } \\
\text { system }\end{array}$} & \multirow{3}{*}{$\begin{array}{l}\text { Land use } \\
\text { type }\end{array}$} & \multicolumn{5}{|c|}{ Land footprint of livestock production of meat and milk } \\
\hline & & \multicolumn{5}{|l|}{ Scenarios } \\
\hline & & S1 & $\mathrm{S} 2$ & S3 & S4 & S5 \\
\hline \multirow{3}{*}{ Arid } & Grassland & $1,915,650$ & $1,915,650$ & $1,915,650$ & $1,122,750$ & 780,500 \\
\hline & Feed cropland & - & - & - & - & - \\
\hline & Total & $1,915,650$ & $1,915,650$ & $1,915,650$ & $1,122,750$ & 780,500 \\
\hline \multirow{3}{*}{ Semi-arid } & Grassland & $1,045,000$ & 742,500 & 570,600 & 454,750 & 269,300 \\
\hline & Feed cropland & 4850 & 307,350 & 479,250 & 11,900 & 5000 \\
\hline & Total & $1,049,850$ & $1,049,850$ & $1,049,850$ & 466,650 & 274,300 \\
\hline \multirow{3}{*}{ Humid } & Grassland & 752,100 & 422,200 & 209,650 & 387,250 & 167,500 \\
\hline & Feed cropland & 132,400 & 462,300 & 674,850 & 135,750 & 418,300 \\
\hline & Total & 884,500 & 884,500 & 884,500 & 523,000 & 585,800 \\
\hline \multirow{3}{*}{ Total } & Grassland & $3,712,750$ & $2,783,300$ & $2,197,600$ & $1,964,750$ & $1,217,300$ \\
\hline & Feed cropland & 137,200 & 765,900 & $1,146,250$ & 147,600 & 423,300 \\
\hline & Total & $3,850,000$ & $3,850,000$ & $3,850,000$ & $2,112,400$ & $1,640,600$ \\
\hline
\end{tabular}


advances from scenarios S4 to S5 in the humid system. This is despite the increased FCE and carcass yield in S5. The highest rate of land use, $0.3 \mathrm{ha} / \mathrm{t}$ and 11.9 ha/t for milk and meat production, respectively, were recorded for scenario S1 in the arid system. Scenario S5 in the humid production system exhibits the lowest level of land use per tonne, $0.11 \mathrm{ha} / \mathrm{t}$ for cattle milk and 0.72 ha/t for sheep and goat meat, even after allowing for cropland use. Scenario S5 exhibits the largest cropland footprint for both milk and meat, 0.09 ha/t and 1.79 ha/t, respectively. Overall, land use per tonne of product is highest for cattle due to their poorer feed conversion efficiency relative to that for shoats. We omit the results for camel as we did not analyse the effect of the changes in productivity on camel milk and meat production under the five scenarios.

\section{Discussion}

In this section we discuss the implications of increased livestock production with intensification on food security in Kenya in Section 4.1 through to Section 4.2. We then discuss levels of intensification under the five scenarios and how they affect land use in Section 4.3.

\subsection{Increased livestock production potential or output}

Recognition of the challenges likely to be posed by the projected growth in demand for livestock products to natural resources has prompted diverse stakeholders to form alliances, such as the multistakeholder forum under the Global Agenda of Action, to consider how best to bridge the efficiency gap and improve other aspects of livestock production (FAO, 2013). The production scenarios we consider represent possible paths to increasing production within the prevailing land constraints. The increased production under scenarios S2 and S3 is rather large and may seem hard to attain in practice. The absolute improvements in meat and milk production per animal are, from very low levels, about $5 \mathrm{~kg} / \mathrm{cow} /$ day to $20 \mathrm{~kg} / \mathrm{cow} /$ day for milk and about $76 \mathrm{~kg} /$ animal to $216 \mathrm{~kg} /$ animal for carcass yield. In the humid mixed crop-livestock systems, there are far more opportunities to improve milk production than in the drier semi-arid and arid systems. Furthermore, dairy production is currently the most economically important livestock production activity in Kenya (Behnke and Muthami, 2011). It would therefore be worthwhile exploring how to further improve productivity in this sector within the humid production system, including the development of synergies between crop and livestock production (Tarawali et al., 2011). When considered alongside the exceptional returns on investment realised in the humid system (Nicholson et al., 2004), dairy production in this system shows the greatest promise to improve livestock productivity in Kenya. However, there is increasing realisation that future production improvements will need to be more targeted at the small rural farmer communities, increased efficiency of production and developing more market-oriented systems of both production and supply chains (Headey and Jayne, 2014). The current rapid urbanisation in Kenya, with a doubling in urban population size expected by 2050 (UN, 2014), will almost certainly accelerate the development of urban markets, and hence increase the flow of products from the farm gate to the urban consumers, and hopefully raise the income of livestock farmers.

In order to make more land available for feed crops, it will be important to sensitize the farmers on the opportunities to meet both food and feed production and benefit from dairy and meat production. This would be achievable if the key elements of intensification embodied in scenarios S2 and S3 are adopted and practiced by farmers. Nevertheless, most farmers will likely not have sufficient resources and technical know-how to make the changes necessary to benefit from the anticipated increase in output from improved management practices and the associated enhanced productivity (Upton, 2004). This calls for investment by governments and other development actors to enable farmers acquire the resources and skills needed to improve productivity of the indigenous breeds of cattle and small ruminants in the low-input systems (Klapwijk et al., 2014).

Our results show that opportunities for meat productivity improvements are much larger in the arid and semi-arid systems than in the humid systems. We also show that the increase in production of meat from scenarios S2 to S3 expected for cattle in the humid systems is not likely to be realised due to the suboptimal FCE relative to the current high cropland use in scenario S3. In the drier areas, where the common livestock breeds thrive on a diet composed mainly of natural grasses and produce below their potential, there are more opportunities to improve meat production. Hence, we expect large changes in production in these systems as productivity increases from the baseline scenario $\mathrm{S} 1$ to scenarios S2 and S3. These potential productivity improvements are already being realized in private ranches in these systems. Here, pure breeds, like the Boran, and their crosses with exotic breeds, e.g. Simmental, are reared under exclusive grazing and feed supplementation, making it possible for farmers to obtain relatively high carcass yields (Kahi et al., 2006). In the humid system, there are more constraints on land for livestock production and stronger influences of other factors. For example, better access to markets for the increased output, especially for milk, have led to the adoption of various production intensification strategies (Udo et al., 2011).

\subsection{Implications for food security}

Poverty and the associated high levels of malnutrition are a major and persistent challenge for many African countries (FAO et al., 2014). Sustainable intensification of production thus presents a viable pathway to effectively confronting both challenges in a world with finite land resources and a rapidly expanding human population. Although staple crops dominate the diets in many African countries, the domestically generated supply of these cereals is often below per capita requirements. In Kenya, this is linked to continued reliance on relief food in several arid and semi-arid areas. Though this is not always as much a problem of production as it is of food distribution, there is no gainsaying that large parts of Kenya, especially the arid and semi-arid areas that produce most of the meat consumed in Kenya, are currently extremely food insecure. That $40 \%$ of land considered unsuitable for cultivation is currently under cultivation in the semiarid system is a strong indication of a growing need to contain rising levels of food insecurity and the need to enhance productivity by promoting and encouraging (e.g., through providing incentives) land uses optimal or appropriate for particular production systems or agro-climatic zones.

Increasing the production of milk and meat through intensification would raise the level of food security and enable farmers to increase their incomes from livestock and enhance their ability to purchase food and meet other family needs, like better health care and education. However, allowance needs to be made for the fact that any benefits from intensification of production would need to be adjusted for the various trade-offs of implementing the associated innovations. Accordingly, an analysis that evaluates all the costs and risks associated with intensification for individual farmers would help further clarify and strengthen the argument for increased income to farmers due to intensifying their livestock production enterprises.

Another pertinent issue to consider is the rate of Kenyan population growth. Although the actual growth rate has slowed down in recent years, projections point to about a $60 \%$ increase in the coming 20 years (UN, 2013). This underscores the extreme importance and urgency of investing in increasing agricultural productivity to meet the projected upsurge in demand. Finally, because it can simultaneously increase production, income and nutritional security of small-scale farming families, and save land for other uses such as conservation, intensification holds the greatest promise to successfully improving livestock production in Kenya. 


\subsection{Decline in quantity of land used through intensification of production}

Land scarcity is a major constraint to livestock production in the semi-arid and humid production systems. Almost $40 \%$ of the area already cultivated in the semi-arid and humid production systems occupies land not considered as highly suitable for crop production. This indicates a greater demand for cropland than what is currently available. However, both the semi-arid and humid systems have land under pasture, which is classified as highly suitable for crop production, and so could be converted to produce both food and feed. In addition, if the level of intensification were advanced from the current level, S1, to productivity scenarios S4 and S5, more land under pasture could also become available for crop production.

Conversion of suitable grassland to crop production provides the opportunity to meet the twin objectives of increasing both ruminant livestock output and relieving the constraint of unavailability of land for livestock production. This can be accomplished through the cultivation of dual purpose high-yielding crops for both food and feed, such as sweet potatoes (Ipomoea batatas), maize (Zea mays), cowpeas (Vigna unguiculata) and groundnuts (Arachis hypogaea). Such crops are being developed to aid the adoption of improved technologies such as exotic livestock breeds that require more fodder and concentrates to ensure optimal production (Blümmel et al., 2003; Claessens et al., 2008). Conflicts between the production of food and feed crops will remain though. Currently, 36\% of the calories produced by the world's crops are being used for animal feed, but due to conversion losses only $12 \%$ of those feed calories ultimately contribute to the human diet, as meat and other animal products (Cassidy et al., 2013).

The pressure on land for livestock production is highest in the semi-arid system, where land availability for agriculture is lowest. This finding adds a quantitative dimension to and reaffirms similar conclusions derived from qualitative analysis carried out by Shiferaw (2002). It is mainly the relatively higher rainfall levels in the semi-arid areas than in the arid system that facilitates crop-livestock interactions and increases land demand in these zones. Land scarcity in this system can be alleviated by adopting production of drought-resistant and yield-improved dual-purpose crops such as sorghum (Sorghum bicolor), thereby improving both farmer nutrition and livestock feed supply (Sutherland et al., 1999; Olembo et al., 2010). Additionally, through the intensification process embodied in scenarios S4 and S5, the consequent land sparing effect would avail more land for maintaining wildlife and other ecosystem goods and services that promote ecosystem health and the resilience of socio-ecological systems (Foley et al., 2005).

For the arid system, there are seemingly vast grasslands for livestock production. Production in this system relies on seasonal access to the grasslands due to large seasonal variability in pasture availability. However, the operation of many biophysical and non-biophysical processes, such as land fragmentation through fencing (Ogutu et al., 2013; Ogutu et al., 2014), and rising conflicts over access rights to water and pasture, hinder production in these systems by putting additional constraints on the availability and use of these vast grasslands for livestock production. Such constraints are hard to capture by the methods we used to assess resource use on these grasslands, so our estimates of the availability of these grasslands for livestock production are probably overestimates. Additionally, the availability of grazing land in this system is likely to be further reduced by the increasing frequency and severity of droughts (Williams et al., 2012), natural resource conflicts (Menkhaus, 2015) land degradation (Mundia and Aniya, 2006), large scale mining and infrastructure development. Due to these and other constraining factors, the opportunities and prospects for improving production at the croplivestock interface in these dryland systems are currently very limited (Robinson et al., 2015). Most gains in the livestock sector in this system will thus likely be realized by enhancing production efficiency, increasing resilience to diseases and droughts as envisioned under scenarios S4 and S5. Additionally, due to the high availability of grazing land at the current numbers of livestock, there exists a high potential to increase herd size and total output from cattle, sheep and goats.

A valuable extension of the assessment of land availability for livestock production should entail estimation of the total biomass available for grazing and browsing in each of the production systems. Such biomass estimates corrected for proper use factors and harvestable biomass fraction before multiplication with the available land area (De Leeuw and Wilson, 1987; De Leeuw and Tothill, 1990; FAO, 2010), could deliver improved and more accurate estimates of the attainable livestock production increase under different scenarios.

As livestock production practices become more intensified in Kenya, we expect a reduction in the average herd sizes used for production. Currently, herders keep huge herds for a variety of reasons, including coping with risks and cultural reasons, such as prestige, and not necessarily due to economic considerations per se. Consequently, the expectation of a reduction in the average herd size with advancing intensification implicitly assumes huge changes in the behaviour of hundreds of thousands of farmers and herders and that the relevant and enabling policies, institutional arrangements, markets, supporting information, services, inputs, and other essential requirements will be made available, accessible and affordable in order to realize the potential of the contemplated intensification (Biggs, 2007). The reduction in herd sizes with increasing intensification would be expected to be more pronounced in the arid and semi-arid areas than in the humid areas where herd sizes are already small. Furthermore, even though the reduction in herd sizes following intensification would mirror that associated with the change from pastoralism to settled agro-pastoralism, the farmers would likely derive greater benefits from the few herds than do agro-pastoralists, if intensification would increase livestock productivity beyond the levels achievable under agro-pastoralism. Although the anticipated meat and milk yields under the most productive scenario, $\mathrm{S} 3$, are quite modest relative to the yields realized under similar climatic conditions, for example in Australia, the decline in land use due to intensification from scenario S1 to S5 is quite high, approximately $100 \%$ overall. Decreased demand on land associated with advanced intensification would reduce the pressure on land, allowing rotational grazing and fallow periods. Reduced pressure on land would also free up land for the preservation and conservation of biodiversity and ecosystem services, reduce habitat degradation, which is currently widespread in Kenya (Bai and Dent, 2006), and allow for recovery of the already degraded habitats (Georgiadis et al., 2007; Navarro and Pereira, 2012).

\section{Conclusion}

Our findings highlight the potential for intensifying livestock production in Kenya and the associated trade-offs, which can be summarized as follows.

1. It is potentially possible to expand the production of meat by $71 \%$ and of milk by $51 \%$ in Kenya using the currently available cropland. Meat production could even be increased by as much as $113 \%$ and milk production by up to $80 \%$ by increasing ruminant productivity and availing additional cropland for livestock production. However, both scenarios have costs and risks associated with intensification of production on the available cropland which would need to be taken into account.

2. The competition between the production of feed crops required to support production under the anticipated intensification, and production of food crops, biofuels as well as space for the rapidly expanding human settlements, is likely to be intense because the land area currently under feed crops would need to be expanded by $50-300 \%$, at the expense of the other competing land uses. Increasing the role of crop residues and other food by-products in livestock diets would help ease the pressure to expand croplands for exclusively producing livestock feeds. 
3. The arid systems have the greatest potential to increase overall meat production under improved management practices in Kenya. But milk production by cattle in the humid system possesses the highest potential for increasing production to meet the projected increase in demand and ensure self-sufficiency in milk supply in Kenya. It is noteworthy, however, that challenges presented by diseases and pests along with other social and cultural constraints (e.g. freeranging goats limiting intensification efforts; the women who are responsible for many livestock activities having limited decision-making power and accessibility to the income earned) in the lowland humid areas are huge, and have severely slowed the adoption and development of profitable dairy enterprises unless promoted by big external donor funded projects.

4. Increasing productivity of livestock, food and feed crops would reduce the demand for even more land for production and hence avail more land for environmental conservation, settlements, infrastructure development and other uses. Environmental conservation can be enhanced by confining livestock to less land using, for example, zero-grazing as is currently practiced in the humid system. As the zero-grazed animals are stall fed, cultivation of feed can be carried out in a manner that ensures little degradation of landscapes and that degraded landscapes are restored through appropriate cultivation practices.

\section{Acknowledgements}

CKB was funded by the NUFFIC Netherlands Fellowship Programme and the CGIAR Research Program Livestock and Fish (L\&F). The contribution by JdL was supported by the CGIAR Research Program on Dryland Systems (DS), JOO was supported by a grant from the German Research Foundation (DFG, Research Grant \#OG 83/1-1), and ML was supported by the CGIAR Research Program on Water, Land and Ecosystems (WLE).

\section{References}

Angelsen, A., 1995. Shifting cultivation and deforestation - a study from Indonesia. World Dev. 23, 1713-1729.

Bai, Z., Dent, D., 2006. Global assessment of land degradation and improvement: pilot study in Kenya. ISRIC Rep.

Behnke, R., Muthami, D., 2011. The contribution of livestock to the Kenyan economy. IGAD LPI Working Paper.

Bett, H.K., Musyoka, M.P., Peters, K.J., Bokelmann, W., 2012. Demand for meat in the rural and urban areas of Kenya: a focus on the indigenous chicken. Econ. Res. Int. 2012, 10.

Biggs, S., 2007. Building on the positive: an actor innovation approach to finding and promoting pro-poor institutional and technical innovations. Int. J. Agric. Resour. Gov. Ecol. 6, 144-164.

Bilsborrow, R.E., Ogendo, H., 1992. Population-driven changes in land use in developing countries. Ambio 21, 37-45.

Blümmel, M., Zerbini, E., Reddy, B., Hash, C., Bidinger, F., Khan, A., 2003. Improving the production and utilization of sorghum and pearl millet as livestock feed: progress towards dual-purpose genotypes. Field Crop Res. 84, 143-158.

Bosire, C.K., Ogutu, J.O., Said, M.Y., Krol, M.S., Leeuw, J.d., Hoekstra, A.Y., 2015. Trends and spatial variation in water and land footprints of meat and milk production systems in Kenya. Agric. Ecosyst. Environ. 205, 36-47.

Bouwman, A.F., Van der Hoek, K.W., Eickhout, B., Soenario, I., 2005. Exploring changes in world ruminant production systems. Agric. Syst. 84, 121-153.

Cassidy, E.S., West, P.C., Gerber, J.S., Foley, J.A., 2013. Redefining agricultural yields: from tonnes to people nourished per hectare. Environ. Res. Lett. 8, 034015.

Claessens, L., Stoorvogel, J., Antle, J.M., 2008. Ex ante assessment of dual-purpose sweet potato in the crop-livestock system of Western Kenya: a minimum-data approach. Agric. Syst. 99, 13-22.

De Leeuw, P., Rey, B., 1995. Analysis of current trends in the distribution patterns of ruminant livestock in tropical Africa. People 11, 24.

De Leeuw, P.N., Tothill, J.C., 1990. The Concept of Rangeland Carrying Capacity in SubSaharan Africa: Myth or Reality. Overseas Development Institute, Pastoral Development Network London.

De Leeuw, P.N., Wilson, R.T., 1987. Comparative productivity of indigenous cattle under traditional management in subSaharan Africa. Q. J. Int. Agric. 26, 377-390.

Delgado, C.L., 2003. Rising consumption of meat and milk in developing countries has created a new food revolution. J. Nutr. 133, 3907S-3910S.

FAO, 2010. LADA Land Use System Maps. Food and Agriculture Organization.

FAO, 2013. Greening Livestock Sector Growth: Closing the Efficiency Gap in Natural Resource Use. Food and Agiculture Organization, Rome. Italy.
FAO, IFAD, WFP, 2014. The State of Food Insecurity in the World 2014: Strengthening the Enabling Environment for Food Security and Nutrition. Food and Agriculture Organization of the United Nations (FAO), Rome, Italy.

Feder, G., Umali, D.L., 1993. The adoption of agricultural innovations: a review. Technol Forecast. Soc. Chang. 43, 215-239.

Foley, J.A., DeFries, R., Asner, G.P., Barford, C., Bonan, G., Carpenter, S.R., Chapin, F.S., Coe, M.T., Daily, G.C., Gibbs, H.K., 2005. Global consequences of land use. Science 309, 570-574.

Georgiadis, N.J., Olwero, J.G.N., Ojwang', G., Romañach, S.S., 2007. Savanna herbivore dynamics in a livestock-dominated landscape: I. Dependence on land use, rainfall, density, and time. Biol. Conserv. 137, 461-472.

Godfray, H.C.I., Beddington, I.R., Crute, I.R., Haddad, L., Lawrence, D., Muir, J.F., Pretty, I. Robinson, S., Thomas, S.M., Toulmin, C., 2010. Food security: the challenge of feeding 9 billion people. Science 327, 812-818.

Grandin, B.E., 1988. Wealth and pastoral dairy production: a case study from Maasailand Hum. Ecol. 16, 1-21.

Headey, D.D., Jayne, T.S., 2014. Adaptation to land constraints: is Africa different? Food Policy 48, 18-33.

Herrero, M., Havlík, P., Valin, H., Notenbaert, A., Rufino, M.C., Thornton, P.K., Blümmel, M. Weiss, F., Grace, D., Obersteiner, M., 2013. Biomass use, production, feed efficiencies, and greenhouse gas emissions from global livestock systems. Proc. Natl. Acad. Sci. 110, 20888-20893.

ILRI, 2010. East African Dairy Development Project Baseline Survey: Feeds and Feeding Practices. International Livestock Research Insitute.

Jankhe, H.E., 1982. Livestock Production Systems and Livestock Development in Tropical Africa. Kieler Wissenchaftsveerlag Vauk, Kiel, Germany.

Kahi, A.K., Wasike, C.B., Rewe, T.O., 2006. Beef production in the arid and semi-arid lands of Kenya: constraints and prospects for research and development. Outlook Agric. 35, 217-225.

Kastner, T., Rivas, M.J.I., Koch, W., Nonhebel, S., 2012. Global changes in diets and the consequences for land requirements for food. Proc. Natl. Acad. Sci. 109, 6868-6872.

Klapwijk, C., Bucagu, C., van Wijk, M., Udo, H., Vanlauwe, B., Munyanziza, E., Giller, K. 2014. The 'one cow per poor family' programme: current and potential fodder availability within smallholder farming systems in Southwest Rwanda. Agric Syst. 131, 11-22.

Koh, L.P., Lee, T.M., 2012. Sensible consumerism for environmental sustainability. Biol Conserv. 151, 3-6.

Marra, M., Pannell, D.J., Abadi Ghadim, A., 2003. The economics of risk, uncertainty and learning in the adoption of new agricultural technologies: where are we on the learning curve? Agric. Syst. 75, 215-234.

Mekonnen, M.M., Hoekstra, A.Y., 2011. The green, blue and grey water footprint of crops and derived crop products. Hydrol. Earth Syst. Sci. 15, 1577-1600.

Mekonnen, M.M., Hoekstra, A.Y., 2012. A global assessment of the water footprint of farm animal products. Ecosystems 15, 401-415.

Menkhaus, K., 2015. Conflict Assessment: Northern Kenya and Somaliland (Available at SSRN 2589109).

Mundia, C.N., Aniya, M., 2006. Dynamics of landuse/cover changes and degradation of Nairobi City, Kenya. Land Degrad. Dev. 17, 97-108.

Navarro, L., Pereira, H., 2012. Rewilding abandoned landscapes in Europe. Ecosystems 15, 900-912.

Ndambi, O.A., Hemme, T., Latacz-Lohmann, U., 2007. Dairying in Africa - status and recent developments. Livest. Res. Rural. Dev. 19

Ngigi, S., 2002. Review of Irrigation Development in Kenya. International Water Management Institute, Colombo, Sri Lanka.

Nicholson, C.F., Thornton, P.K., Muinga, R.W., 2004. Household-level impacts of dairy cow ownership in coastal Kenya. J. Agric. Econ. 55, 175-195

Ogutu, J.O., Owen-Smith, N., Piepho, H.-P., Said, M.Y., Kifugo, S.C., Reid, R.S., Gichohi, H. Kahumbu, P., Andanje, S., 2013. Changing wildlife populations in Nairobi National Park and adjoining Athi-Kaputiei Plains: collapse of the migratory wildebeest. Open Conserv. Biol. J. 7, 11-26.

Ogutu, J.O., Piepho, H.-P., Said, M.Y., Kifugo, S.C., 2014. Herbivore dynamics and range contraction in Kajiado County Kenya: climate and land use changes, population pressures, governance, policy and human-wildlife conflicts. Open Ecol. J. 7, 9-31

Olembo, K., M'mboyi, F., Kiplagat, S., Sitieney, J., Oyugi, F., 2010. Sorghum Breeding in Sub-Saharan Africa: The Success Stories. The Africa Biotechnology Stakeholders Forum (ABSF) Publ, Nairobi, Kenya.

Omore, A., Muriuki, H., Kenyanjui, M., Owango, M., Staal, S., 1999. The Kenyan Dairy Sub-Sector: A Rapid Appraisal: Research Report of the MoA/KARI/ILRI Smallholde Dairy (R\&D) Project. International Livestock Research Institute, Nairobi (Kenya) (51 pp.).

Ouda, J.O., 2001. Feeding and care of livestock. Managing Dryland ResourcesA Manual for Eastern and Southern Africa. International Institute for Rural Reconstruction (IIRR).

Ouma, E., Staal, S., Omore, A., Wanjohi, P., Njoroge, L., Njubi, D., 2000. Consumption Patterns of Dairy Products in Kenya. KARI/MoARD/ILRI Report.

Owen, E., Smith, T., Makkar, H., 2012. Successes and failures with animal nutrition practices and technologies in developing countries: a synthesis of an FAO e-conference. Anim. Feed Sci. Technol. 174, 211-226.

Pelletier, N., Tyedmers, P., 2010. Forecasting potential global environmental costs of livestock production 2000-2050. Proc. Natl. Acad. Sci. 107, 18371-18374.

Place, F., Njuki, J., Murithi, F., Mugo, F. 2006. Agricultural enterprise and land management in the highlands of Kenya. Strategies for Sustainable Land Management in the East African Highlands, pp. 191-215.

Pratt, D.J., Gwynne, M.D. (Eds.), 1977. Rangeland Management and Ecology in East Africa. Hodder and Stoughton, London.

Pretty, J., Toulmin, C., Williams, S., 2011. Sustainable intensification in African agriculture. Int. J. Agric. Sustain. 9, 5-24. 
Randolph, T., Schelling, E., Grace, D., Nicholson, C.F., Leroy, J., Cole, D., Demment, M., Omore A., Zinsstag, J., Ruel, M., 2007. Invited review: role of livestock in human nutrition and health for poverty reduction in developing countries. J. Anim. Sci. 85, 2788-2800.

Rege, J., 2001. Zebu Cattle of Kenya: Uses, Performance, Farmer Preferences, Measures of Genetic Diversity and Options for Improved Use. ILRI (aka ILCA and ILRAD).

Robinson, T., Thornton, P., Franceschini, G., Kruska, R., Chiozza, F., Notenbaert, A., Cecchi, G., Herrero, M., Epprecht, M., Fritz, S., 2011. Global Livestock Production Systems. Food and Agriculture Organization of the United Nations (FAO).

Robinson, L.W., Ericksen, P.J., Chesterman, S., Worden, J.S., 2015. Sustainable intensification in drylands: what resilience and vulnerability can tell us. Agric. Syst. 135, 133-140.

Ruigu, G.M., 1988. Large-scale Irrigation Development in Kenya: Past Performance and Future Prospects.

Shiferaw, B., 2002. Poverty and Natural Resource Management in the Semi-arid Tropics: Revisiting Challenges and Conceptual Issues. ICRISAT.

Steinfeld, H., Gerber, P., Wassenaar, T., Castel, V., Rosales, M., Haan, C., 2006. Livestock's Long Shadow: Environmental Issues and Options. Food and Agriculture Organization, Rome.

Sutherland, A., Irungu, J., Kang'ara, J., Muthamia, J., Ouma, J., 1999. Household food security in semi-arid Africa-the contribution of participatory adaptive research and development to rural livelihoods in Eastern Kenya. Food Policy 24, 363-390.

Tarawali, S., Herrero, M., Descheemaeker, K., Grings, E., Blümmel, M., 2011. Pathways for sustainable development of mixed crop livestock systems: taking a livestock and pro-poor approach. Livest. Sci. 139, 11-21.

Tilman, D., Cassman, K.G., Matson, P.A., Naylor, R., Polasky, S., 2002. Agricultura sustainability and intensive production practices. Nature 418, 671-677.
Tilman, D., Balzer, C., Hill, J., Befort, B.L., 2011. Global food demand and the sustainable intensification of agriculture. Proc. Natl. Acad. Sci. 108, 20260-20264.

Tscharntke, T., Clough, Y., Wanger, T.C., Jackson, L., Motzke, I., Perfecto, I., Vandermeer, J., Whitbread, A., 2012. Global food security, biodiversity conservation and the future of agricultural intensification. Biol. Conserv. 151, 53-59.

Udo, H.M.J., Aklilu, H.A., Phong, L.T., Bosma, R.H., Budisatria, I.G.S., Patil, B.R., Samdup, T., Bebe, B.O., 2011. Impact of intensification of different types of livestock production in smallholder crop-livestock systems. Livest. Sci. 139, 22-29.

UN, 2013. World Population Prospects: The 2012 Revision. Population Division of the Department of Economic and Social Affairs of the United Nations Secretariat.

UN, 2014. 2014 Revision of World Urbanization Prospects.

Upton, M., 2004. The Role of Livestock in Economic Development and Poverty Reduction (Page 57 pp).

van Velthuizen, H., Huddleston, B., Fischer, G., Salvatore, M., Ataman, E., Nachtergaele, F.O., Zanetti, M., Bloise, M., Antonicelli, A., Bel, J., 2007. Mapping biophysical factors that influence agricultural production and rural vulnerability. 9251056897, Food and Agriculture Organization, Rome, Italy.

Williams, A.P., Funk, C., Michaelsen, J., Rauscher, S., Robertson, I., Wils, T.G., Koprowski, M., Eshetu, Z., Loader, N., 2012. Recent summer precipitation trends in the Greater Horn of Africa and the emerging role of Indian Ocean Sea surface temperature. Clim. Dyn. 39, 2307-2328.

Wirsenius, S., Azar, C., Berndes, G., 2010. How much land is needed for global food production under scenarios of dietary changes and livestock productivity increases in 2030? Agric. Syst. 103, 621-638. 